\title{
EARLY BYZANTINE OFFICIALS IN THE SOUTHWESTERN TAURICA ACCORDING TO THE SEALS FROM CHERSON AND ITS ENVIRON
}

\author{
Nikolay A. Alekseienko \\ Institute of Archaeology of Crimea of the Russian Academy of Sciences, Simferopol, Russian Federation
}

\begin{abstract}
Introduction. Written sources and epigraphic monuments reflecting the history of Early Byzantine Cherson keep a few isolated accounts of some representatives of a large imperial administrative apparatus, which certainly existed in the city from the late $5^{\text {th }}$ to the $8^{\text {th }}$ century (komes, bikarios, doux, and archon). Methods. Sigillographic monuments supply some extra information of the stratum of local officials in the period under consideration. The set of seals of Chersonites and their addressees from the early Byzantine period allows to uncover a variety of correspondents from military and civil departments (magistros, stratelates, droungarios, kommerkiarios, notarios, magistrianos, arkarios, hermeneutes, and others). In my point of view, these sources indicate parallel local officials who worked in Cherson and its environs, show that the city established appropriate bureaucratic offices, and inform of its rather high status as an important strategic, administrative, and economic stronghold. Analysis. Today it is possible to enlarge this group with several new seals from the $6^{\text {th }}$ to the $8^{\text {th }}$ century, partially originating from the vicinity of Cherson. There are molybdoboulla of asekretis, referendarios, chartoularios, genikos kommerkiarios, komes and senator - illoustrios. Results. This way, the early Byzantine seals of Cherson and its neighbourhood supply reasons to consider that, from the $6^{\text {th }}$ to the $8^{\text {th }}$ century, this provincial centre got a number of various magistracies to control different aspects of the city life, from common records management to land register, foreign trade, and diplomatic missions sent by the basileus.
\end{abstract}

Key words: Byzantine history, Byzantine Cherson, sigillography, seals, molybdobullae.

Citation. Alekseienko N.A. Early Byzantine Officials in the Southwestern Taurica According to the Seals from Cherson and Its Environ. Vestnik Volgogradskogo gosudarstvennogo universiteta. Seriya 4. Istoriya. Regionovedenie. Mezhdunarodnye otnosheniya [Science Journal of Volgograd State University. History. Area Studies. International Relations], 2019, vol. 24, no. 6, pp. 95-110. (in Russian). DOI: https://doi.org/10.15688/jvolsu4.2019.6.8

\section{РАННЕВИЗАНТИЙСКОЕ ЧИНОВНИЧЕСТВО В ЮГО-ЗАПАДНОЙ ТАВРИКЕ В СВЕТЕ СФРАГИСТИЧЕСКИХ ДАННЫХ ИЗ ХЕРСОНА И ЕГО ОКРУГИ}

\author{
Николай Александрович Алексеенко \\ Институт археологии Крыма РАН, г. Симферополь, Российская Федерация
}

\begin{abstract}
Аннотация. В письменных источниках и памятниках эпиграфики, отражающих историю ранневизантийского Херсона, сохранились единичные, отрывочные сведения лишь о некоторых представителях обширного имперского бюрократического аппарата, несомненно существовавшего здесь в конце V - VIII в. (комит, викарий, дука, архонт). В какой-то мере дополнительные данные о местном чиновничьем сословии этого ¿ периода позволяют получить памятники сфрагистики. Ассортимент печатей чиновников-херсонитов и их адресантов, относящихся к ранневизантийскому времени, дает возможность представить достаточно широкий спектр разнообразных корреспондентов как из военных, так и из гражданских ведомств (магистр, стратилат, друнгарий, коммеркиарий, нотарий, магистриан, аркарий, эрнемент-переводчик и др.), что, на наш взгляд, свидетельствует не только об очевидном существовании в Херсоне и его округе аналогичных местных чиновников, но и о наличии в городе соответствующих бюрократических служб, что, в свою очередь, говорит (2) о его достаточно высоком статусе важного стратегического, административного и экономического центра.
\end{abstract}




\section{ВИЗАНТИЙСКАЯ СФРАГИСТИКА}

Сегодня к этой группе адресантов Херсона мы можем присоединить несколько новых печатей VI-VIII вв., часть из которых происходит и с территории херсонской округи. Это моливдовулы референдария Константина (VI - рубеж VI/VII вв.), хартуляриев Феопемта (VI-VII вв.) и Феодора (VII в.), комитов Феодора (конец VI в.) и Константина (VII в.), секретаря-асикрита Феофана (VII-VIII вв.), главного коммеркиария Феодора (VIII в.) и сенатора-иллюстрия Сергия (вторая половина VI - начало VII в.). Таким образом, ранневизантийские печати из византийского Херсона и его периферии дают основания полагать, что в VI-VIII вв. городской уклад этого провинциального центра империи, судя по всему, был достаточно обеспечен разнообразными ведомственными чиновниками, которые контролировали самые различные сферы городской жизнедеятельности - от обычного делопроизводства до контроля над земельным кадастром, внешней торговлей и обеспечением дипломатических поручений василевса.

Ключевые слова: история Византии, византийский Херсон, сфрагистика, печати, моливдовулы.

Цитирование. Алексеенко Н. А. Ранневизантийское чиновничество в юго-западной Таврике в свете сфрагистических данных из Херсона и его округи // Вестник Волгоградского государственного университета. Серия 4, История. Регионоведение. Международные отношения. - 2019. - T. 24, № 6. - С. 95-110. - DOI: https://doi.org/10.15688/jvolsu4.2019.6.8

Введение. Сохранившиеся в анналах истории сведения о ранневизантийском бюрократическом аппарате в Таврике не только малочисленны, но и достаточно малоинформативны. Источники сообщают нам лишь отрывочные сведения об отдельных персонажах, находившихся в то время на вершине административной пирамиды власти в Херсоне, и в большинстве своем умалчивают об исполнителях других многочисленных и не менее важных постов.

В первую очередь отметим хорошо известные памятники эпиграфики, которые повествуют о том, что в самом конце V в. (488 г.) одним из представителей местной администрации был комит Диоген [14, с. 10-15], а византийским гарнизоном Херсона командовал викарий $[21$, с. 559, 560]. Известно также, что в конце VI в. в Таврике появляется должность дуки Херсона [14, с. 105-109], юрисдикция которого, по мнению ряда исследователей, могла распространяться на весьма обширную территорию полуострова - от Херсона до Боспора $[1$, с. $132 ; 13$, с. $124 ; 16$, с. 184-186, 620; 19, с. 8]. Однако об административном аппарате Таврического дуката ничего не известно. Уже во второй половине VII в. он был упразднен $[16$, с. $624 ; 17$, с. 208,$209 ; 20]$. И в соответствии со свидетельствами письменных источников, и по данным моливдовулов можно констатировать, что в начале VIII столетия управление переходит уже к архонтам Херсона [11, с. 27-58], юрисдикция которых теперь распространялась только на близлежащий к городу регион Горного Крыма, то есть Юго-Западную Таврику.
Как мы уже отмечали выше, данных о составе местного бюрократического аппарата ранневизантийского времени в источниках нет. Однако, на наш взгляд, дополнительные сведения на этот счет позволяют получить именно памятники сфрагистики.

Meтодbl. Сфрагистическая коллекция Государственного историко-археологического музея-заповедника «Херсонес Таврический», сбор данных о новых находках в округе Херсона, а также детальное рассмотрение ассортимента городских собственников печатей, относящихся к ранневизантийскому времени, и в особенности их адресантов - все это дает возможность представить достаточно широкий спектр разнообразных отправителей служебной корреспонденции в юго-западный регион Таврики, свидетельствующий не только об очевидном существовании в Херсоне, равно как и в его округе (в последнее время на территории городской округи все чаще и чаще стали находить именно ранневизантийские печати), аналогичных местных чиновников, но и о наличии в городе соответствующих бюрократических служб или ведомств, присущих большинству провинциальных центров империи.

Следует заметить, что рассмотрение этого достаточно обширного пласта сфрагистических памятников далеко не всегда дает возможность подтвердить или дополнить свидетельства других источников. Так, несмотря на эпиграфические свидетельства о дукате Херсона, печати местных дук нам до сих пор неизвестны (гипотеза С.Б. Сорочана на этот счет пока остается лишь гипотезой [17]). 
В то же время среди сфрагистических находок присутствуют моливдовулы целого ряда представителей различных чиновничьих должностей, которые в известной мере позволяют представить местный уклад жизни этого времени с его своеобразием и спецификой.

Основной задачей и целью настоящей работы являются рассмотрение всех доступных сфрагистических памятников из Херсона и его округи (с безусловным введением в научный оборот ранее неизвестных моливдовулов) и проведение анализа этих данных в сопоставлении со свидетельствами письменных источников для определения по возможности наиболее полного перечня представителей бюрократического аппарата, функционировавших на территории Юго-Западной Таврики с конца VI по начало VIII в., и выявления их контактов с коллегами из центра и других византийских провинций.

Анализ. К сожалению, к печатям, принадлежащим, на наш взгляд, представителям местного херсонского аппарата управления рассматриваемой эпохи, можно предположительно отнести лишь единственный моливдовул, который в данном контексте мы атрибутировали как печать патера полиса Херсона (VI-VII вв.) [11, с. 410, 411, № III.7.1 $\left.{ }_{1-2}\right]$. Но и здесь все-таки еще остается вопрос о правомерности такой расшифровки монограммы, определяющей имя и пост владельца печати. Как известно, канонических законов составления монограмм в Византии не существовало, и в этой связи правильное чтение монограмм во многих случаях создает серьезные трудности для исследователей. Так что и в нашем случае возможна многовариантность прочтения.

В то же время ряд печатей херсонского сфрагистического собрания, не содержащих топонимических указаний, может указывать на представителей имперской администрации, связанных с исполнением важных государственных функций. В качестве таких примеров можно назвать моливдовулы второй половины VI - первой половины VII в. - сборщика налогов - аркария Анания или переводчика эрменеита Стефана [15, с. 206, № 13-15], хотя Н.И. Храпунов не исключает возможности их принадлежности и к представителям местной администрации [20, с. 46-48].
Присутствие среди находок в Херсоне булл известных военачальников Юстиниана I магистра Бизацены, кувикулярия и императорского спафария Иоанна Троглиты [5, с. 351, 352 , № 1, рис. 1] и стратилата Заида [6, с. 368, 369, № 3], участвовавших вместе с Велизарием в африканских походах около середины VI в., одного из византийских флотоводцев, друнгария Михаила (VIII в.) [4, с. 9, 11, № 2, рис. 1,9], комита Опсикия, патрикия Артавазда (первая половина VIII в.), на вершине своей карьеры ставшего византийским императором [2], коммеркиариев Феодора (конец VI - начало VII в.) и Исидора (VII в.) [9, с. 8 , 9 , № 2; 15, с. 208 , № 26], нотария Феодора (VII в.), императорского магистриана Анфима (конец VII - начало VIII в.) [15, с. 209, 213, № 38,56$]$ и ряда других, несомненно, свидетельствует о неизменном внимании к региону со стороны высокопоставленных византийских чиновников различных служб и ведомств и достаточно высоком статусе Херсона, начиная с самого раннего этапа его средневековой истории, как важного стратегического, административного и экономического центра.

Сегодня к этой группе адресантов Херсона и его округи мы можем присоединить несколько новых печатей ${ }^{1}$.

Во-первых, здесь можно назвать традиционных для многих византийских центров гражданских чиновников - секретарей-асикритов. Среди булл комплекса херсонского архива печатей [3] выявлены два моливдовула VII-VIII вв., весьма вероятно принадлежавшие одному и тому же персонажу, имя которого - Феофан.

1. Феофан, асикрит, раб (слуга) Богородицы (рис. 1).

Akh-23. Музей А. Шереметьева (Киев). $\mathrm{D}$ - ок. $25 \mathrm{~mm}$; толщина заготовки - 2$3 \mathrm{~mm}$.

Сохранность: заготовка малого модуля; ободок и край легенды частично вышли за край заготовки; слегка децентрирована вправо; незначительные разрывы поля на концах канала; помята в верхней части; покрыта черной патиной.

Происхождение: найдена в Херсонесе (архив); из коллекции Ю. Самойленко.

Аналогий нет. Не издана. 
Аверс. В ободке из листвы - четырехстрочная надпись:

\begin{tabular}{|c|c|}
\hline.$€$ & {$[\Theta] \varepsilon o$} \\
\hline QANIO. & 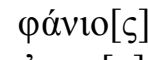 \\
\hline $\begin{array}{l}\text { ACHK. } \\
\text { HTIC }\end{array}$ & $\begin{array}{l}\alpha \partial \sigma \eta \kappa[\rho] \\
\tilde{n} \tau 1 c\end{array}$ \\
\hline
\end{tabular}

Реверс. В ободке из слившихся в линию жемчужин - четырехстрочная надпись:

\begin{tabular}{|c|c|}
\hline$+\Delta \gamma$ & $\Delta$ (ov́) \\
\hline ^૪ТHC̣ & $\lambda(\mathrm{ov}) \tau \tilde{\eta} \mathrm{s}$ \\
\hline$\Theta \in O T$. & $\Theta \varepsilon o \tau[o ́]$ \\
\hline Kठ & $\kappa(\mathrm{ov})$ \\
\hline
\end{tabular}

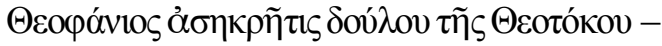
Феофан, асикрит, раб (слуга) Богоматери.

2. Феофан, императорский асикрит, раб (слуга) Богородицы (рис. 2).

Akh-81. Музей А. Шереметьева (Киев). $\mathrm{D}$ - $22 \mathrm{~mm}$; толщина заготовки - ок. $1 \mathrm{~mm}$.

Сохранность: заготовка малого модуля; ободок и край легенды частично вышли за край заготовки; незначительные разрывы поля на концах канала; покрыта черной патиной со следами белого налета.

Происхождение: найдена в Херсонесе (архив); из коллекции Ю. Самойленко.

Аналогий нет. Не издана.

Аверс. В ободке из листвы - четырехстрочная надпись:

\begin{tabular}{|c|c|}
\hline$\cdots$ & {$[\Theta \varepsilon]$} \\
\hline ФQ̣NIO & [o]póvio[s] \\
\hline R.ACHK & $\beta(\alpha \sigma \imath \lambda ı \kappa o ̀ \varsigma) \dot{\alpha} \sigma \eta \kappa$ \\
\hline PHT, & $\rho \tilde{\eta} \tau(1 \zeta)$ \\
\hline
\end{tabular}

Реверс. В ободке из листвы - четырехстрочная надпись:

\begin{tabular}{|c|c|}
\hline$+\Delta \gamma$ & $\Delta$ (oú) \\
\hline ^૪ТНФ̣ & $\lambda(\mathrm{ov}) \tau \tilde{\eta}$ \\
\hline$\Theta \in O T$. & $\Theta \varepsilon 0 \tau[0 ́]$ \\
\hline K ठ & $\kappa(\mathrm{ov})$ \\
\hline
\end{tabular}

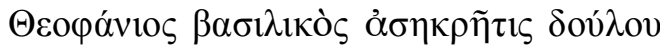

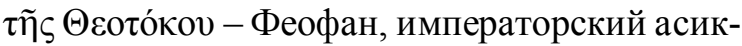
рит, раб (слуга) Богоматери.

Стилистические особенности обеих печатей (билатеральный сфрагистический тип; крупный квадратный шрифт) позволяют отнести их к памятникам VII-VIII столетий. Близкие по типу печати с аналогичной датировкой хорошо известны в византийской сфрагистике (см., к примеру: [33, p. 569, 576, 586, nr. 774, $789,812]$ и др.).

Как видно из легенды на первой печати, наш персонаж представлен в чине асикрита, на другой - уже императорского асикрита.

Согласно данным источников, чином асикрита первоначально (VI в.) обладали только секретари императорской канцелярии. В дальнейшем последние появились в большинстве имперских служб и ведомств, а сама должность приобрела более универсальные функции, не связанные с исполнением именно секретарских обязанностей. В то же время известно, что императорским асикритам поручались ответственные дипломатические задания, кроме того, они выполняли важные личные поручения императоров [23, p. 97, 98]. Нередко асикриты, причем как ведомственные, так и императорские, назначались для проведения различных ревизионных проверок, в том числе и налоговых.

В случае с Херсоном присутствие здесь печатей асикритов, надо полагать, является дополнительным свидетельством существования постоянного контроля со стороны высокопоставленных лиц имперской канцелярии за состоянием дел на полуострове в период сложных внутри- и внешнеполитических отношений в VII - начале VIII столетия.

К этой группе булл, очевидно, следует отнести еще одну печать с изображением крестообразных монограмм на обеих сторонах, владельцем которой, по нашему мнению, был референдарий Константин.

3. Константин, референдарий (рис. 3). Akh-189. Музей А. Шереметьева (Киев). $\mathrm{D}$ - $24 \mathrm{~mm}$; толщина заготовки $-3 \mathrm{~mm}$.

Сохранность: слегка децентрирована; ободок частично вышел за край заготовки; разрывы поля на концах канала; покрыта черной патиной. Происхождение: найдена в Херсонесе (архив); из коллекции Ю. Самойленко.

Аналогий нет. Не издана.

Аверс. Крестообразная монограмма имени владельца, состоящая из греческих букв: слева $-\mathrm{N}$; в центре - ; справа $-\mathrm{K}$; сверху - Т и дифтонг ૪; внизу - А . 
Реверс. Крестообразная монограмма должности владельца, состоящая из греческих букв: слева $-\mathrm{N}$; в центре - вертикальная лигатура $\mathrm{P}$, ф и К (?); справа - Е; сверху - дифтонг ૪; внизу - лигатура $\Delta$ со вписанной в нее $A$.

Присутствие в монограмме дифтонга б показывает, что зашифрованные в монограммах имя и должность владельца представлены в родительном падеже.

К сожалению, точных аналогий представленным на печати монограммам обнаружить не удалось. Тем не менее атрибутировать наш памятник возможно по известным в византийской сфрагистике монограммам с близким начертанием. Имя владельца моливдовула достаточно уверенно определяется по двум группам булл из коллекции Г. Закоса, первая из которых относится ко второй половине VI первой половине VII в. [33, p. 377, 378, nr. 306, 309, 3012, pl. 237,290-293], а вторая - к VIII столетию [33, p. 1032, 1033, 1047, nr. 1811, 1839, pl. 237,293]. Наиболее близко нашему начертание в монограмме, представленной на печати № 3012 первой группы, которую издатели отнесли к VII столетию. Наш экземпляр, бесспорно, тяготеет к этой группе и стилистически: на нем помещены только имя и должность владельца; в то время как на печатях второй группы уже появляется и монограмма с инвокативным обращением к Богоматери.

Имя владельца рассматриваемого моливдовула, безусловно, следует расшифровывать как Константин, представленное в гене-

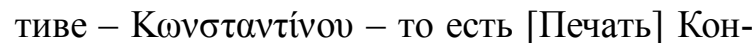
стантина. В то же время следует отметить, что монограмма на херсонском экземпляре дана в зеркальном отображении (ретроградно) и в ней отсутствует сигма.

Что касается расшифровки монограммы оборотной стороны печати, здесь больше трудностей. Идентичной монограммы найти не удалось. И лишь в диссертации В.О. Финка, посвященной эволюции византийских монограмм, представлена близкая по начертанию монограмма на однотипном моливдовуле из коллекции Dumbarton Oaks (DO 58.106.4587), которая расшифрована автором как должность референдария [24, р. 344, nr. 982]. В этой связи мы осмелимся предположить, что и в монограмме херсонской печати также зашифрована эта должность, пред- ставленная, как и имя владельца, в родитель-

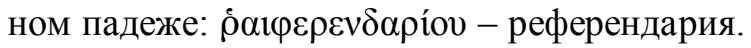

Таким образом, найденная в составе комплекса архива херсонских печатей булла представляет нам ранее неизвестного для крымских находок референдария Константина.

Монограммные печати исследователи датируют по-разному, в зависимости от характера представленного на них шрифта и начертания отдельных литер, толщины и диаметра заготовки, о чем мы упоминали выше. Стилистические особенности рассматриваемого моливдовула и использование в шрифте аль$\phi b l$ с ломаной центральной гастой, характерной для датированных печатей середины второй половины VII в. [28, p. 166], позволяют нам отнести данный памятник к рубежу VI/VII вв. - первой половине VII века.

Заметим, что в византийских источниках референдарий упоминается прежде всего как государственный служащий центральной администрации, хотя эта должность известна и в провинциальных городах. Как секретарь императора референдарий играл заметную роль в деле управления государством, особенно в эпоху Юстиниана I (527$565)$. В его обязанности входили сбор и подача прошений императору, а также передача высочайших повелений василевса и ответов монарха просителям. Е. Штайн отмечает, что в начале VII столетия референдарии полностью исчезли из имперской канцелярии, уступив место асикритам [31, p. 738]. В дальнейшем этот чин более не использовался в имперской практике. И, судя по византийским табелям о рангах, только в Х в. он вновь появляется в административной практике, но на этот раз в середине перечня из одиннадцати архонтов патриарха, занимая лишь седьмое место вслед за протонотарием и канстрисисом $\left[27\right.$, p. $\left.251_{24}\right]$.

Появление корреспонденции референдария в Херсоне, по всей видимости, может быть связано с его основной функцией поверенного между просителями и василевсом. Не исключено, что печатью референдария было скреплено послание, связанное с обращением когото из херсонитов к императору.

Наряду с асикритами и референдарием на печатях херсонского архива представлены и другие важные чиновники. Яркими приме- 


\section{ВИЗАНТИЙСКАЯ СФРАГИСТИКА}

рами тому служат моливдовулы хартуляриев Феопемта (VI-VII вв.) и Феодора (VII в.).

4. Феопемпт, хартулярий (рис. 4).

Akh-147. Музей А. Шереметьева (Киев).

D-24 mm; толщина заготовки - ок. 3,5 mm.

Сохранность: разрывы поля на концах канала; вздутие поля на одном из выходов канала на лицевой стороне; покрыта черной патиной; в нижней части небольшой участок гурта покрыт окислами белого цвета.

Происхождение: найдена в Херсонесе (архив); из коллекции Ю. Самойленко.

Аналогий нет. Не издана.

Аверс. В ободке из листвы - фигура святого воина, держащего в правой руке длинный крест, левой опирающегося на стоящий у ног щит, анфас. Легенды нет.

Реверс. В ободке из листвы - четырехстрочная надпись, украшенная сверху небольшим крестиком:

\begin{tabular}{|c|c|}
\hline$\Theta \in 0$ & $\Theta \varepsilon o$ \\
\hline ПЄМП & $\pi \dot{\varepsilon} \mu \pi$ \\
\hline TOVX & $\tau o v \chi$ \\
\hline$A P$, & $\alpha \rho(\tau o v \lambda \alpha \rho i ́ o v)$ \\
\hline
\end{tabular}

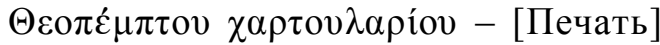
Феопемпта, хартулярия.

Стилистические особенности моливдовула (не подписанное изображение святого воина, держащего вместо копья мученический крест, ободок из листвы) дают все основания отнести данный моливдовул к памятникам конца VI - середины VII столетия.

Имя Феопемпта - очень редкое в византийской сфрагистике. В этой связи привлекает внимание печать одноименного чиновника из собрания Г. Закоса. Несмотря на то что она представляет иной сфрагистический тип (монограммный), аналогичный выше рассмотренной печати референдария Константина, не исключено, что перед нами две разные печати одного чиновника, который в ходе своей карьеры сменил один буллотирий на другой. Печать из собрания Г. Закоса датируется издателями 550-650 гг. [33, p. 474, nr. 555].

Тип изображения фигуры неизвестного воина-мученика, в которой исследователи предполагают изображение св. Феодора, из- вестен не только по коллекции Г. Закоса [33, p. 790-794, nr. 1282-1291]. Аналогичный экземпляр присутствует в собрании Афинского нумизматического музея [34, б. 168, 169 , $\alpha \rho t \theta$. 533]. В большинстве своем эти печати датируются в пределах второй половины VI середины VII века. Тип рассматриваемой печати представлен на абсолютно тождественном по стилю моливдовуле Теосебия из коллекции Г. Закоса, который датирован издателями 550-650 гг. [33, p. 794, nr. 1290a-b]. Думается, нет оснований сомневаться в том, что моливдовул Феопемпта, хартулярия из Херсона, также принадлежит этому времени. Единственное, что пока не представляется возможным определить - которая из печатей более ранняя - монограммная или херсонская с изображением св. воина.

5. Феодор, хартулярий (рис. 5).

Akh-182. Музей А. Шереметьева (Киев). $\mathrm{D}-21 \times 27 \mathrm{~mm}$ (диаметр поля матрицы $20 \mathrm{~mm})$; толщина заготовки - ок. $3 \mathrm{~mm}$.

Сохранность: заготовка овальной формы; на лицевой стороне ободок частично вышел за край заготовки, справа разрыв поля на конце канала; покрыта черной патиной со следами белого налета.

Происхождение: найдена в Херсонесе (архив); из коллекции Ю. Самойленко.

Аналогий нет. Не издана.

Аверс. Крестообразная инвокативная

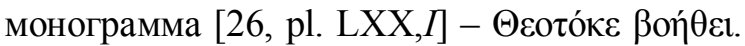
В поле по углам четыре крестика (два верхних не сохранились (?)). Изображение заключено в веревочный (?) ободок или ободок из листвы.

Реверс. Четырехстрочная надпись в веревочном (?) ободке или ободке из листвы:

\begin{tabular}{|c|c|}
\hline$+\Theta \in O$ & $\Theta \varepsilon o$ \\
\hline$\triangle \omega P \omega V X$ & $\delta \omega \rho \omega \chi$ \\
\hline$D \wedge \wedge$ & $\alpha \rho \tau o v \lambda$ \\
\hline PIW & $\alpha \rho i ́ \omega$ \\
\hline
\end{tabular}

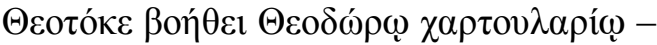
Богородица, помоги твоему рабу Феодору, хартулярию.

Печати с изображением инвокативной монограммы без сопровождения формулы $\tau \widetilde{\omega} \sigma \widetilde{\omega} \delta$ ov́ $\lambda \omega$ (твоему рабу) - датируются, как правило, VII-VIII веками. Тип, представленный на нашем моливдовуле, достаточно хоро- 
шо известен и встречается как в сопровождении крестов, так и без них. К примеру, на печати патрикия Калинника (VIII в.) в углах монограммы изображены четыре креста, а на булле Феодора без указания должности владельца (первая половина VII в.) монограмма украшена лишь двумя крестами в ее нижних секторах [33, p. 902, 938, nr. 1526, 1617]. Не исключено, что и на херсонском моливдовуле представлен именно такой вариант. Очень близок по стилю к рассматриваемой печати моливдовул доместика Феодора (VII в.), на котором, правда, монограмма представлена без каких-либо украшений [33, p. 942, nr. 1629]. Одноименность владельцев и стилистическая близость печатей в последнем примере, безусловно, не дает нам оснований говорить об их принадлежности одному сигиллянту, однако приведенные выше аналогичные моливдовулы указывают на то, что печать хартулярия Феодора следует датировать в пределах VII столетия.

Исходя из данных источников, изначально хартулярии являлись высокопоставленными государственными служащими, следившими в провинциях за имперскими землями. Их роль состояла в том, чтобы сохранять общее состояние провинциального кадастра, главным образом в крупных городах, и контролировать финансы фем [23, p. 87]. Позже, в средневизантийское время, они появились практически во всех гражданских, военных и церковных ведомствах и в основном их назначение сводилось к ведению различной документации.

На наш взгляд, собственников херсонских моливдовулов, учитывая их датировку ранневизантийским временем, скорее всего, следует рассматривать как представителей столичного фискально-податного ведомства. Конечно, невозможно определить адресатов, кому была направлена их корреспонденция, но, очевидно, это был кто-то из представителей официального аппарата, управлявшего в то время Херсоном, среди которого, надо полагать, мог находиться и соответствующий местный кадастровый чиновник.

К группе печатей, имеющих отношение к ведомству имперского фиска, принадлежит и моливдовул, владельцем которого был главный коммеркиарий Феодор (VIII в.).
6. Феодор, апоипат и главный коммеркиарий (рис. 6).

Akh-18. Музей А. Шереметьева (Киев). $\mathrm{D}-26 \mathrm{~mm}$; толщина заготовки - ок. $3 \mathrm{~mm}$.

Сохранность: заготовка малого модуля; ободок и края легенды частично вышли за край заготовки; незначительные разрывы поля на концах канала; покрыта черной патиной.

Происхождение: найдена в Херсонесе (архив); из коллекции Ю. Самойленко.

Аналогий нет. Не издана.

Аверс. Четырехстрочная надпись (ободок вышел за край заготовки):

\begin{tabular}{|c|c|}
\hline & \\
\hline$\triangle W P V$ & $\Delta \omega ́ \rho($ ov $)$ \\
\hline АПОУП & 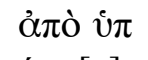 \\
\hline & $\alpha ́ \alpha \omega[v]$ \\
\hline
\end{tabular}

Реверс. Четырехстрочная надпись(ободок вышел за край заготовки):

\begin{tabular}{|c|c|}
\hline Sг€̣ & 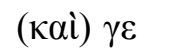 \\
\hline NIK OVK & viкоv $\mathrm{K}$ \\
\hline OVMEPK! & оv $\mu(\mu) \varepsilon \rho \kappa \iota$ \\
\hline $\mathrm{AP}$ & $\alpha \rho($ íov $)$ \\
\hline
\end{tabular}

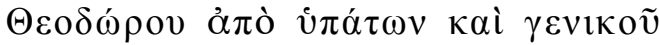

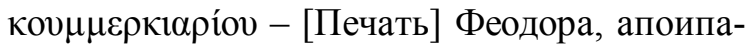
та и главного коммеркиария.

Печати так называемого билатерального типа с надписью на обеих сторонах бытуют в сфрагистической практике в VI-VIII вв. и в XI столетии. Применение легенды без формулы инвокативного обращения и отсутствие характерных литер для шрифтов VI и XI столетий предполагают датировку данного моливдовула в пределах VII-VIII веков. Вместе с тем одна из печатей собрания Г. Закоса, на наш взгляд, позволяет значительно ее сузить. Речь идет о печати апоипата Феодора, диойкита эпарха, которую издатели датировали второй половиной VII в. [33, р. 677, nr. 1031]. Внешний вид печатей настолько близок, что складывается впечатление об их принадлежности одному мастеру, по крайней мере одной мастерской. Легенды лицевых сторон полностью совпадают и по начертанию литер, и по их расстановке в строках. Полагаем, что оба экземпляра принадлежали одному и тому же сигиллянту, который в ходе своей служеб- 


\section{ВИЗАНТИЙСКАЯ СФРАГИСТИКА}

ной карьеры при получении новой должности сменил старый буллотирий на новый. Сложно определить, которая из должностей предшествовала другой; обе печати хронологически очень близки. Тем не менее принадлежность обеих ведомству главного логофета и их соответствующий статус [27, p. 313], на наш взгляд, все же позволяют представить их последовательность.

Содержание легенд на печатях Феодора показывает, что сначала он в ранге апоипата занимал пост главного коммеркиария, очевидно возглавляя бюро коммеркиариев в столице империи (поскольку на печати не назван провинциальный регион), которое обеспечивало сбор пошлин и уплату таможенных сборов, а затем получил новую должность, с нашей точки зрения более значимую, - диойкита эпарха - чиновника, который руководил сбором всех налогов в византийской столице (подробнее см.: [23, p. 88, 89]).

Рассматриваемый херсонский моливдовул вместе с другими уже известными и ранее изданными печатями этого круга $[7 ; 8]$ демонстрирует очевидное осуществление контроля над внешней торговлей в юго-западной Таврике задолго до появления собственной таможни в Херсоне. Судя по всему, в городе существовали и местные функционеры, отвечавшие за эту сферу деятельности в регионе, которым, безусловно, и направлялась соответствующая корреспонденция.

Еще один чин административных управленцев представляют моливдовулы комитов Феодора (конец VI в.) и Константина (VII в.).

Первого из них представляет небольшая по размеру печать с весьма редкой для Херсона греко-латинской легендой.

7. Феодор, комит (рис. 7).

Akh-96. Музей А. Шереметьева (Киев).

$\mathrm{D}$ - $20 \mathrm{~mm}$; толщина заготовки - $3 \mathrm{~mm}$.

Сохранность: заготовка малого модуля; ободок частично вышел за край заготовки; слегка децентрирована вверх; незначительные разрывы поля на концах канала; покрыта черной патиной.

Происхождение: найдена в Херсонесе (архив); из коллекции Ю. Самойленко.

Аналогий нет. Не издана.

Аверс. Блоковая монограмма из латинских букв в ободке из листвы: слева под гори- зонтальной гастой $-\tau$; справа $-\mathrm{h}$; слева над горизонтальной гастой восьмилучевая звезда - ; справа - R. Расшифровка - Theodori Феодора.

Реверс. Крестообразно расположенная надпись латинскими буквами (латинская калька с греческого в родительном падеже) в ободке из листвы:

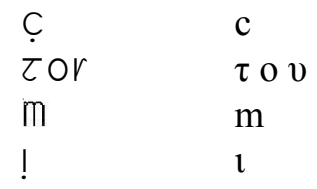

Theodoricomitou - [Печать] Феодора, комита.

По стилистическим признакам печать, безусловно, принадлежит к памятникам VIVII веков. Подобные примеры хорошо известны по печатям Италии и Сицилии.

Близкую по форме монограмму на одном из греко-латинских моливдовулов второй половины VI - VII в. эрмитажного собрания Е.В. Степанова расшифровывает как имя Феодота (или Феодора) [18, с. $71,122,146$, № 89]. В упоминавшейся выше диссертации В.О. Финка представлено несколько вариантов аналогичной монограммы, которую автор связывает с именем Феодора [24, S. 423-424, Nr. 7781]. На печатях Феодора, хартулярия, из сфрагистического собрания Западного Берлина и коллекции Г. Закоса, которые издатели относят к VI в., также представлена подобная монограмма, но более сложной формы [30, S. 40, Nr. 14, Taf. 2,14; 34 p. 458, 516, pl. 61,516]. Наиболее близки к нашей печати моливдовулы Феодора, патрикия, на которых аналогичная нашей монограмма (но с изображением креста вместо звезды) также сопровождается надписью [33, p. 462, 463, nr. 526a-b, 527]. Эти печати датированы второй половиной VI века. Очевидно, и херсонскую находку следует относить к этому же периоду.

8. Константин, комит (рис. 8).

Akh-336. Музей А. Шереметьева (Киев). $\mathrm{D}-10 \times 13 \mathrm{~mm}$; толщина заготовки $-3 \mathrm{~mm}$. Сохранность: заготовка малого модуля прямоугольной формы; ободок и края легенды частично вышли за край заготовки; на лицевой стороне - разрыв поля на конце канала; покрыта черной патиной. 
Происхождение: найдена в Херсонесе (архив); из коллекции Ю. Самойленко.

Аналогий нет. Не издана.

Аверс. Крестообразная инвокативная монограмма [26, pl. LXX,VIII] в ободке из листвы - Kúрıє ßой $\theta \varepsilon ı$.

Реверс. Остатки надписи в три строки (ободок практически не сохранился; не исключено - жемчужный):

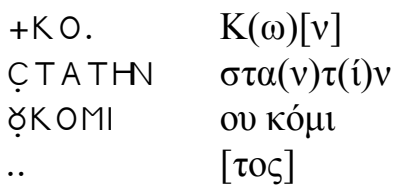

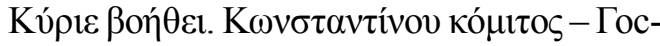
поди, помоги. [Печать] Константина, комита.

Так же как и представленная выше печать хартулярия Феодора (№ 5) с инвокативной монограммой, данный экземпляр, несомненно, относится к памятникам VII в., возможно ко второй половине столетия.

Обращает на себя внимание несогласованность легенд аверса и реверса печати. Инвокативное обращение к Богородице предполагает продолжение легенды в дательном падеже. Тем не менее надпись представлена в генетиве. Своеобразно и начертание имени владельца: в первой строке омега заменена омикроном; во второй - пропущена ню, а иота заменена этой, последняя, в свою очередь, дана в лигатуре со стоящей за ней ню.

В Византийской империи существовало многообразие различных комитов: одни были провинциальными администраторами, в то время как другие выполняли фискальные и экономические функции или выступали в качестве стражей и цензоров; комиты также были младшими офицерами в армии и на флоте $[32$, p. 484, 485].

Не исключено, что наши фигуранты могут быть представителями властей Херсона. Напомним, что в конце $\mathrm{V}$ в. в известном эпиграфическом источнике именно такой пост занимает представитель местной администрации Диоген [14, с. 10-15]. Однако с таким же успехом они могут являться и чиновниками столичной администрации. Учитывая, что в Херсоне преобладают печати представителей имперских финансов, соблазнительно видеть в наших сигиллянтах комитов ведомства глав-

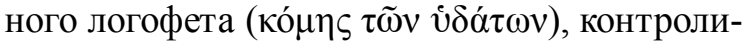
ровавших техническое обслуживание трубопроводов и обеспечивавших водоснабжение [23, p. 87].

И наконец, в завершение хочется привести еще одну печать. Несмотря на то что она не принадлежит к группе должностных булл, однако, на наш взгляд, самым тесным образом связана с темой данного исследования и является ярким примером существования связей обитателей ранневизантийского Херсона и его округи со столицей империи на самом высоком уровне.

Новый моливдовул знакомит нас с ранее не встречавшимся на печатях в Крыму рангом иллюстрия, представленным на моливдовуле с именем Сергия, который недавно был обнаружен в окрестностях византийского Херсона.

9. Сергий, иллюстрий (рис. 9).

Частная коллекция (Севастополь).

$\mathrm{D}$ - $18 \mathrm{~mm}$; толщина заготовки - 2,5 mm.

Сохранность: заготовка малого модуля формы; ободок вышел за край заготовки; желтовато-светло-коричневая патина.

Происхождение: найдена в окрестностях Херсонеса (Гераклейский полуостров).

Аналогий нет. Не издана.

Аверс. Двухстрочная надпись (внешний ободок не сохранился):

$\begin{array}{ll}. \in P & {[\Sigma] \varepsilon \rho} \\ \Gamma I \varnothing & \gamma \text { jíov }\end{array}$

Реверс. Трехстрочная надпись (внешний ободок не сохранился):

$\begin{array}{ll}I \wedge \wedge & i \lambda \lambda \\ \succ C T P & \text { ov } \sigma \rho \\ \text { І } & \text { íov }\end{array}$

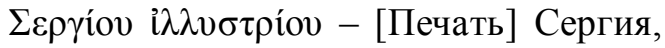
иллюстрия.

Как уже отмечалось выше, печати билатерального типа относятся к двум периодам истории Византии: VI-VII вв. или XI столетию. Стилистические особенности рассматриваемого моливдовула показывают, что данный памятник, вне всякого сомнения, относится к ранневизантийским буллам и его следует датировать в пределах конца VI - начала 


\section{ВИЗАНТИЙСКАЯ СФРАГИСТИКА}

VII века. Точной аналогии данному моливдовулу обнаружить не удалось, однако печати с такой легендой известны. Два экземпляра с греко-латинской надписью, которые датированы издателями VI в., происходят из коллекции Г. Закоса [33, p. 661, nr. 990, 991], и один VIII в. - из собрания Западного Берлина [29, S. 274, 275, Nr. 450].

Как известно, иллюстрий был одним из высших сенаторских титулов в ранней Византии. Реформация сенаторского сословия привела к тому, что в VI в. иллюстрий превратился в фактическое обозначение названия сенаторского звания; стал его синонимом [25, p. 529]. По мнению Т. Брауна, в эпоху Юстиниана I титул иллюстрий был присущ бывшим чиновникам, которые имели соответствующие права на членство в сенате [22, p. 131]. Следует отметить, что, как правило, на этой категории печатей присутствует лишь титул иллюстрия и отсутствует какая-либо чиновничья должность. Е.В. Степанова отмечает, что печати группы иллюстриев (на примере итальянских булл), скорее всего, представляют местных влиятельных собственников, недостатка в которых не было ни в Италии, ни в Сицилии [18, с. 29].

Очевидно, в нашем контексте мы можем рассматривать печать иллюстрия Сергия с хоры византийского Херсона как аналогичный пример, только теперь в применении к территории Таврики. Конечно, это не дает оснований считать владельца печати одним из местных аристократов, принадлежавших к самым высшим слоям византийского общества. Однако появление этого моливдовула - сам по себе факт уникальный. И если даже владелец печати был столичным сановником, а не представителем местной знати, отправка его корреспонденции в Крым является весьма немаловажным фактом, в очередной раз показывающим, что и в ранневизантийскую эпоху контакты местного населения с окружающим миром достигали самого высокого уровня.
Результаты. Последняя находка и другие введенные в научный оборот печати, наряду с уже известными ранее, в очередной раз подтверждают, что Херсон и его администрация уже с ранневизантийского времени имели тесные контакты с различными представителями самых высших кругов империи. Об этом сегодня свидетельствуют уже не только находки императорских печатей $[10$, с. 138 , 139] или одного из высокопоставленных финансовых чиновников - императорского логофета, патрикия Дорофея [12, с. 61-64], но и моливдовулы сенатора-иллюстрия, референдария, хартуляриев и других высокопоставленных чиновников империи.

Таким образом, ранневизантийские печати, происходящие как с территории византийского Херсона, так и его периферии, показывают, что во второй половине VI - начале VIII в. городской уклад жизни этого провинциального центра империи был обеспечен различными представителями обширного бюрократического аппарата империи, которые контролировали самые разные сферы городской жизнедеятельности - от обычного делопроизводства и составления нотариальных актов до контроля за земельным кадастром и внешней торговлей, а также обеспечения дипломатических поручений василевса.

Продолжение исследований в этом направлении и новые находки византийских печатей в Крыму вселяют уверенность, что еще рано ставить точку в решении вопросов административного управления на территории ранневизантийской Таврики, и впереди у нас еще много интересных и важных открытий.

\section{ПРИМЕЧАНИЕ}

1 Автор выражает глубокую благодарность А. Шереметьеву и севастопольским коллекционерам, предоставившим возможность изучения и публикации моливдовулов. 
Н.А. Алексеенко. Ранневизантийское чиновничество в юго-западной Таврике в свете сфрагистических данных

\section{ПРИЛОЖЕНИЕ}
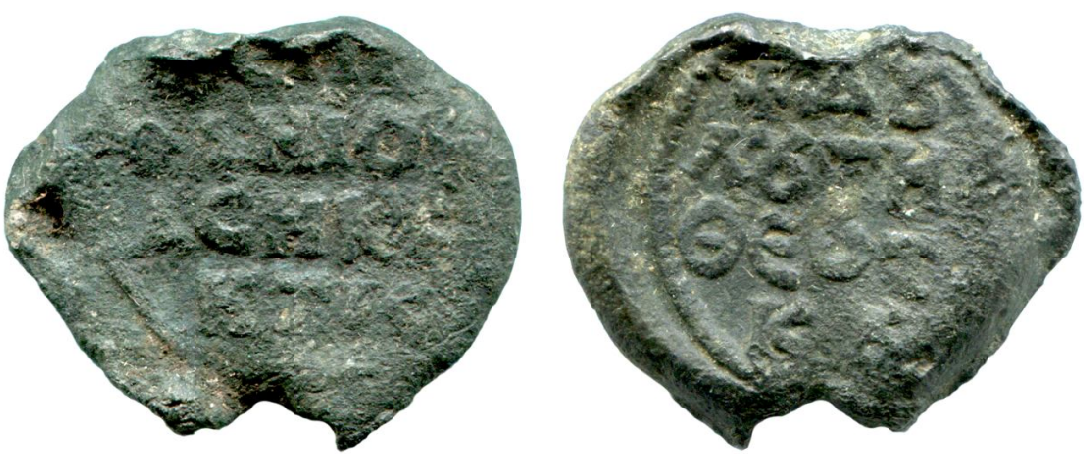

Рис. 1. Печать Феофана, асикрита, слуги Богородицы

Fig. 1. Seal of Theophanes, asecretis and doulou tis Theotokou
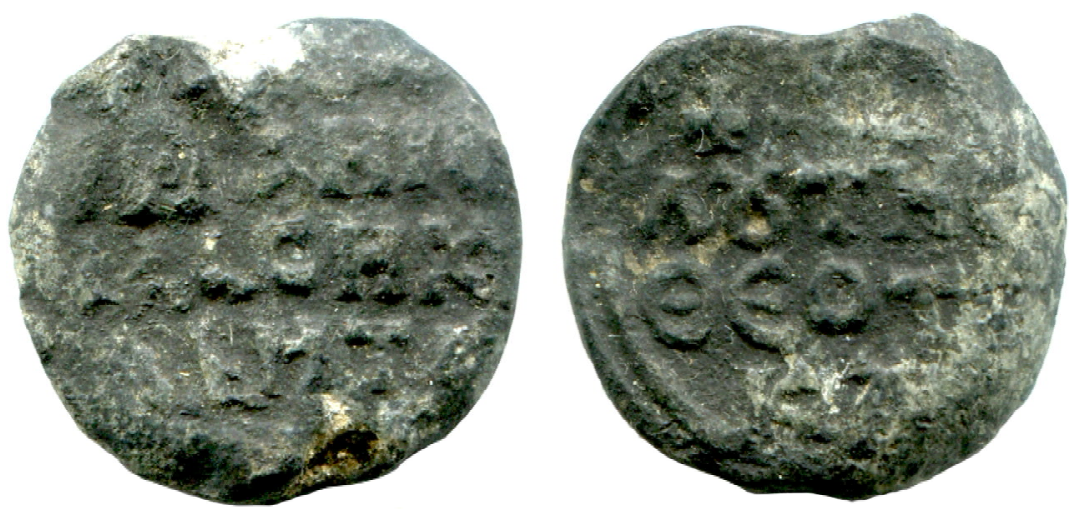

Рис. 2. Печать Феофана, императорского асикрита, слуги Богородицы

Fig. 2. Seal of Theophanes, imperial asecretis and doulou tis Theotokou
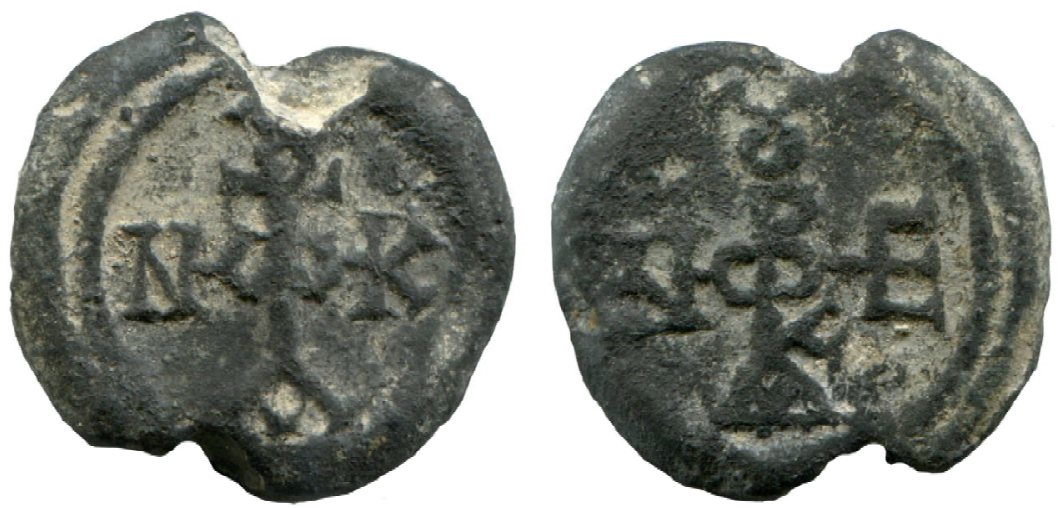

Рис. 3. Печать Константина, референдария

Fig. 3. Seal of Constantine, referendarios 


\section{ВИЗАНТИЙСКАЯ СФРАГИСТИКА}
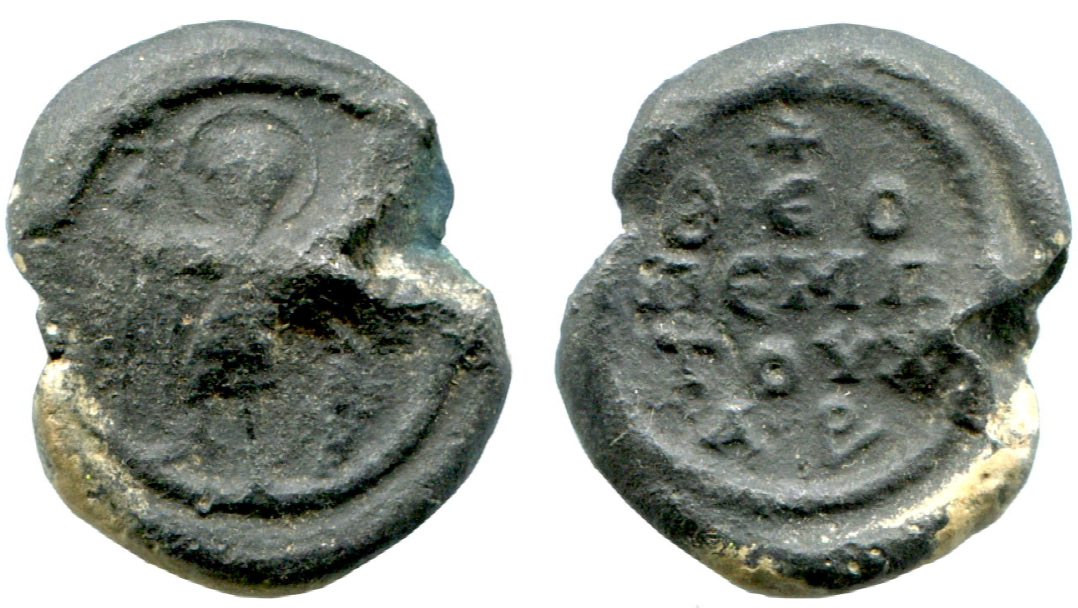

Рис. 4. Печать Феопемта, хартулярия

Fig. 4. Seal of Theopemptos, chartularios
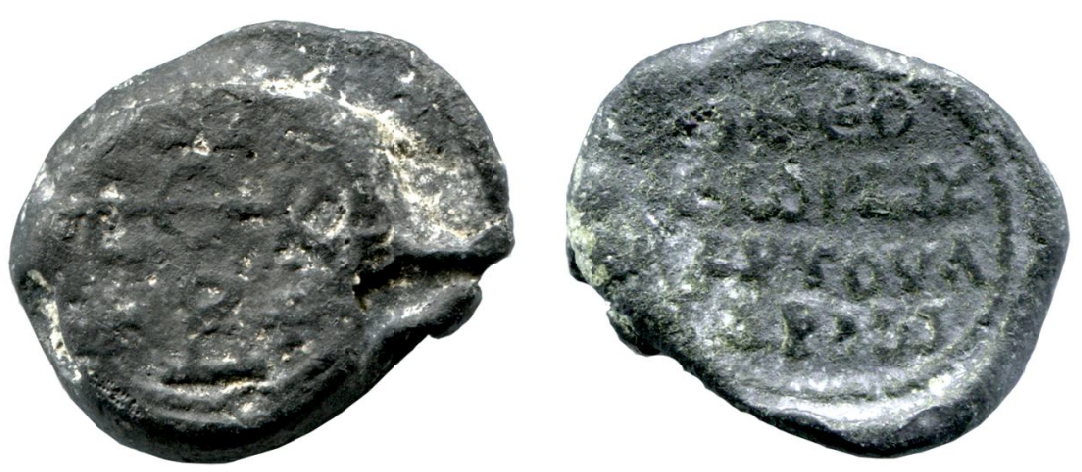

Рис. 5. Печать Феодора, хартулярия

Fig. 5. Seal of Theodore, chartularios
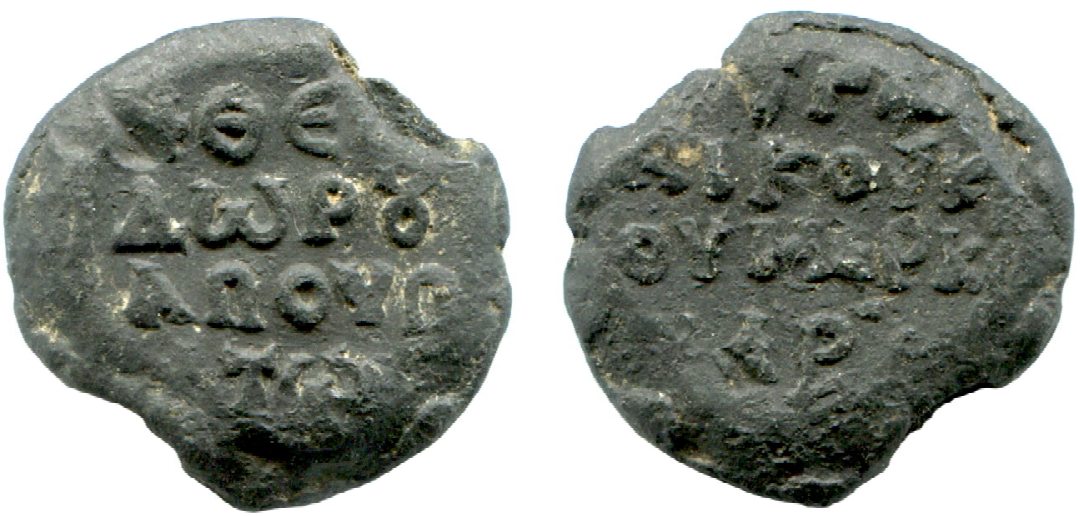

Рис. 6. Печать Феодора, апоипата и главного коммеркиария

Fig. 6. Seal of Theodore, apohypatos and genikos commerciarios 
Н.А. Алексеенко. Ранневизантийское чиновничество в юго-западной Таврике в свете сфрагистических данных
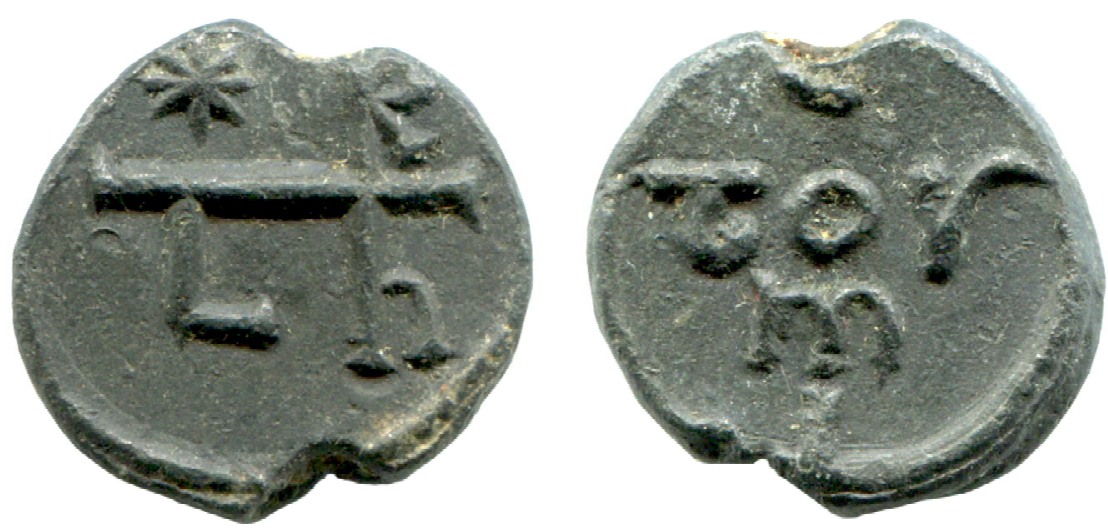

Рис. 7. Печать Феодора, комита

Fig. 7. Seal of Theodore, comes
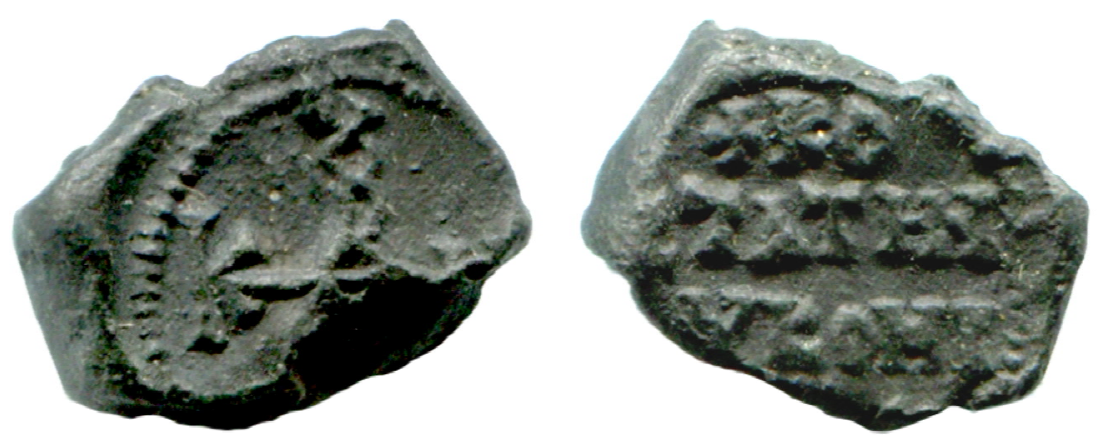

Рис. 8. Печать Константина, комита

Fig. 8. Seal of Constantine, comes
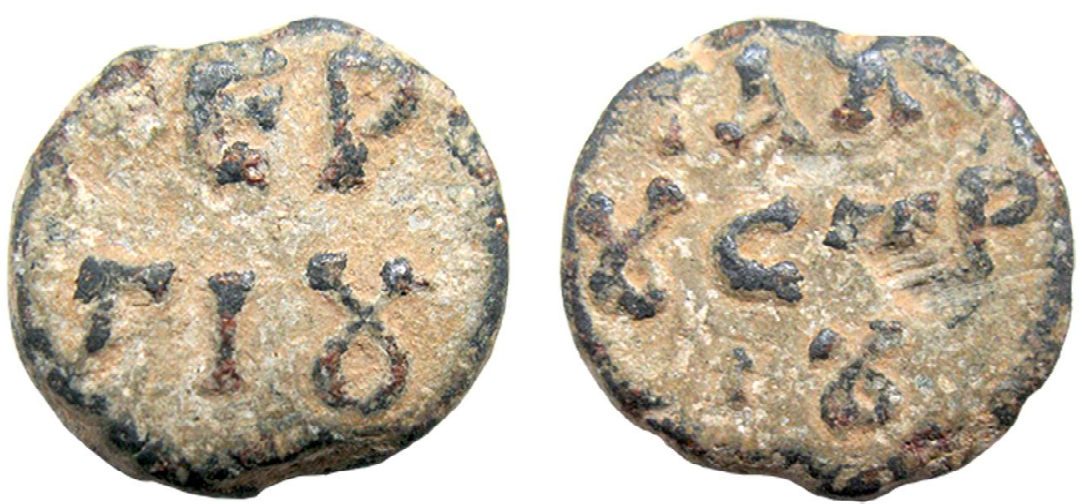

Рис. 9. Печать Сергия, иллюстрия

Fig. 9. Seal of Sergios, illustrios 


\section{СПИСОК ЛИТЕРАТУРЫ}

1. Айбабин, А. И. Этническая история ранневизантийского Крыма / А. И. Айбабин. - Симферополь : Дар, 1999. - 352 с.

2. Алексеенко, Н. А. Моливдовул комита Опсикия начала VIII в. из Херсонеса / Н. А. Алексеенко // Античная древность и средние века. - 1999. Вып. 30. - С. 65-82.

3. Алексеенко, Н. А. «Херсонский архив печатей»: миф или реальность? / Н. А. Алексеенко // Херсонесский сборник. -2006. - Вып. XV.-С. 7-16.

4. Алексеенко, Н. А. Торговый и военный порт византийского Херсона по данным печатей представителей морского ведомства империи / Н. А. Алексеенко // Сугдейский сборник. - 2008. Вып. III. - C. 8-15.

5. Алексеенко, Н. А. «Militaria Byzantina» в Таврике (по данным моливдовулов) / Н. А. Алексеенко // Боспорские исследования. - 2009. Вып. XXI. - С. 350-356.

6. Алексеенко, Н. А. Несколько новых находок ранневизантийских моливдовулов на территории Украины и в Крыму / Н. А. Алексеенко // Сугдейский сборник. - 2010. - Вып. IV. - С. 365-375.

7. Алексеенко, Н. А. Ранневизантийская Таврика в ареале интересов имперских таможен (находки моливдовулов коммеркиариев как отражение процесса развития крымских городских центров в «темные века») / Н. А. Алексеенко // Боспорские исследования. - 2013. - Вып. XXVIII. - С. 275-285.

8. Алексеенко, Н. А. Византийская Таврика в системе имперских финансовых и экономических коммуникаций по данным печатей чиновников фиска и торгово-таможенной службы / Н. А. Алексеенко // Труды Государственного Эрмитажа. 2015. - T. LXXIV. - C. 415-424.

9. Алексеенко, Н. А. Новые сфрагистические находки в окрестностях византийского Херсона (к вопросу об адресатах корреспонденции) / Н. А. Алексеенко // Вестник Волгоградского государственного университета. Серия 4, История. Регионоведение. Международные отношения. - 2016. T. 21, № 5. - C. 6-18. - DOI: http://dx.doi.org/10.15688/ jvolsu4.2016.5.1.

10. Алексеенко, Н. А. «И страж, и пастырь, и купец...» : Византийский Херсон в зеркале данных сфрагистики / Н. А. Алексеенко // Византийский временник. - 2016. - Вып. 75 (100). - С. 133-149.

11. Алексеенко, Н. А. Византийский Херсон VIXIII столетий в памятниках сфрагистики. 1. Чиновники Херсона VIII-XI вв. / Н. А. Алексеенко. - Cевастополь : ООО «Колорит», 2017. - 474 с. - (Крым в истории, культуре и экономике России).

12. Герцен, А. Г. Византийские моливдовулы из раскопок Мангуп-Кале / А. Г. Герцен, Н. А. Алек- сеенко // Античная древность и средние века. 2002. - Вып. 33. - С. 59-65.

13. Зубарь, В. М. О положении Херсона в конце V - VI вв.: политический и экономический аспекты / В. М. Зубарь, С. Б. Сорочан // Херсонесский сборник. - 1998. - Вып. IX. - С. 118-132.

14. Латышев, В. В. Сборник греческих надписей христианских времен из южной России / В. В. Латышев. - СПб. : Изд. Императорского Русского археологического общества, 1896. - 143 с.

15. Соколова, И. В. Византийские печати VIпервой половины IX в. из Херсонеса / И. В. Соколова // Византийский временник. - 1991. - Т. 52. C. 201-213.

16. Сорочан, С. Б. Византийский Херсон (вторая половина VI - первая половина X вв.). Очерки истории и культуры. В 2 ч. Ч. 1 / С. Б. Сорочан. Харьков : Майдан, 2005. - 677 с.

17. Сорочан, С. Б. О дуках византийской Таврики и их моливдовулах / С. Б. Сорочан // Сугдейский сборник. - 2008. - Вып. III. - С. 200-216.

18. Степанова, Е. В. Печати с латинскими и греко-латинскими надписями VI-VIII вв. из собрания Эрмитажа / Е. В. Степанова. - СПб. : Изд-во Гос. Эрмитажа, 2006. - 170 c.

19. Храпунов, М. І. Адміністрація візантійського Херсона (кінець IV-XI ст.) : автореф. дис. ... канд. іст. наук / Микита Ігорович Храпунов. - Київ, 2009. - 20 с.

20. Храпунов, Н.И. К дискуссии о должности дуки Херсона / М. И. Храпунов // Византийский временник. -2011. - Т. 70 (95). - С. 37-50.

21. Цукерман, К. Епископы и гарнизон Херсона в IV веке / К. Цукерман // Материалы по археологии, истории и этнографии Таврии. - 1995. Вып. IV. - C. 545-561.

22. Brown, T. S. Gentlemen and Officers. Imperial Administration and Aristocratic Power in Byzantine Italy A.D. 554-800 / T. S. Brown. London : British School at Rome, 1984. - xiv, 288 p., 3 figs., 2 maps.

23. Bury, J. B. The Imperial Administrative System in the Night Century / J. B. Bury. - London : British Academy Publ., 1911. - 179 p.

24. Fink, W. O. Das byzantinische Monogramm : Diss. zur Erlangung des Doctorgrades / W. O. Fink. Wien, 1971. - $473 \mathrm{~S}$.

25. Jones, A. H.M. The Later Roman Empire, 284 602. Vol. 1 / A. H. M. Jones. - Oxford : Blackwell Publ., 1992. - xv, $766 \mathrm{p}$.

26. Laurent, V. Documents de sigillographie byzantine : La collection C. Orghidan / V. Laurent. Paris : Presses univ. de France, 1952. - 342 p., LXX pl.

27. Oikonomidès, N. Les listes de préséance byzantines des $\mathrm{IX}^{\mathrm{e}}$ et $\mathrm{X}^{\mathrm{e}}$ siècles / N. Oikonomidès. Paris : CNRS, 1972. -403 p. 
28. Oikonomides, N. A Collection of Dated Byzantine Lead Seals / N. Oikonomides. - Washington : Dumbarton Oaks Research Libr. a. Coll., 1986. - 175 p.

29. Sode, C. Byzantinische Bleisiegel in Berlin. T. II/C. Sode. - Bonn : R. Habelt, 1997. - 338 S., 25 Taf. -

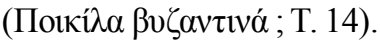

30. Speck, P. Byzantinische Bleisiegel in Berlin (West) / P. Speck. - Bonn : R. Habelt, 1986. - 261 S.,

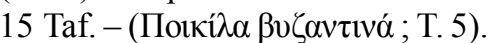

31. Stein, E. Histoire du Bas-Empire. T. II /E. Stein.Paris : Desclée de Brouwer, 1949. - 901 p.

32. The Oxford Dictionary of Byzantium. Vol. I / Eds. A. P. Kazdan [et al.]. - Oxford : Oxford Univ. Pr., 1991.-LI, $728 \mathrm{p}$.

33. Zacos, G. Byzantine Lead Seals / G. Zacos, A. Veglery. - Basel : J.J. Augustin Publ., 1972. - Vol. 1, Pt. I-III. - 1965 p., 260 pl.

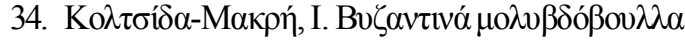

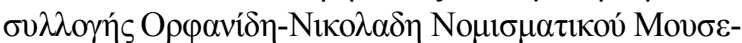

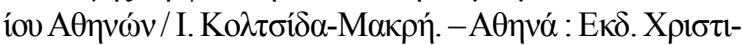

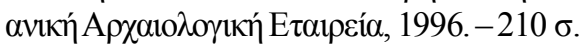

\section{REFERENCES}

1. Aybabin A.I. Etnicheskaya istoriya rannevizantiyskogo Kryma [Ethnic History of Early Byzantine Crimea]. Simferopol, Dar Publ., 1999. 352 p.

2. Alekseienko N.A. Molivdovul komita Opsikiya nachala VIII v. iz Khersonesa [Ein Bleisiegel des Komes von Ospikion vom Beginn des VIII. Jh.s aus Chersonesos]. Antichnaya drevnost $i$ srednie veka, 1999, iss. 30, pp. 65-82.

3. Alekseienko N.A. «Khersonskiy arkhiv pechatey»: mif ili realnost? ["Cherson's Archive of Seals": Myth or Reality?] Chersonesskiy sbornik, 2006, iss. XV, pp. 7-16.

4. Alekseienko N.A. Torgovyy i voennyy port vizantiyskogo Khersona po dannym pechatey predstaviteley morskogo vedomstva imperii [Commercial and Military Port of the Byzantine Cherson According to the Seals of the Maritime Department's Representatives of the Empire]. Sugdeyskiy sbornik, 2008, iss. III, pp. 8-15.

5. Alekseienko N.A. Militaria Byzantina v Tavrike (po dannym molivdovulov) ["Militaria Byzantina" at Taurica]. Bosporskie issledovaniya [Bosporos Studies], 2009, iss. XXI, pp. 350-356.

6. Alekseienko N.A. Neskolko novykh nakhodok rannevizantiyskikh molivdovulov na territorii Ukrainy i v Krymu [Some New Finds of Early Byzantine Molybdobullae in Ukraine and Crimea]. Sugdeyskiy sbornik, 2010, iss. IV, pp. 365-375.

7. Alekseienko N.A. Rannevizantiyskaya Tavrika $\mathrm{v}$ areale interesov imperskikh tamozhen (nakhodki molivdovulov kommerkiariev kak otrazhenie protsessa razvitiya krymskikh gorodskikh tsentrov $\mathrm{v}$ «temnye veka») [Early Byzantine Taurica in the Area of Interest of Imperial Customs (Finds of Commercium Collectors' Molybdoboullos as a Reflection of the Development Process of the Crimean City Centers in the "Dark Ages")]. Bosporskie issledovaniya [Bosporos Studies], 2013, iss. XXVIII, pp. 275-285.

8. Alekseienko N.A. Vizantiyskaya Tavrika $\mathrm{v}$ sisteme imperskikh finansovykh i ekonomicheskih kommunikatsiy po dannym pechatey chinovnikov fiska i torgovo-tamozhennoy sluzhby [Byzantine Taurica in the System of Imperial Financial and Economic Communications According to the Seals of Fisk and Trade and Customs Officials]. Trudy Gosudarstvennogo Ermitazha, 2015, vol. LXXIV, pp. 415-424.

9. Alekseienko N.A. Novye sfragisticheskie nakhodki v okrestnostyakh vizantiyskogo Khersona (k voprosu ob adresatakh korrespondentsii) [New Sphragistic Finds from the Environs of Byzantine Cherson (To the Issue of the Correspondence Adressees)]. Vestnik Volgogradskogo gosudarstvennogo universiteta. Seriya 4, Istoriya. Regionovedenie. Mezhdunarodnye otnosheniya [Science Journal of Volgograd State University. History. Area Studies. International Relations], 2016, vol. 21, no. 5, pp. 6-18. DOI: http://dx.doi.org/10.15688/jvolsu4.2016.5.1.

10. Alekseienko N.A. «I strazh, i pastyr, i kupetz...»: vizantiyskiy Kherson v zerkale dannykh sfragistiki ["Both Guard and Pastor, and Merchant...": Byzantine Cherson in the Reflection of Sigillographic Findings Results]. Vizantiyskiy vremennik [Byzantina Xronika], 2016, iss. 75 (100), pp. 133-149.

11. Alekseienko N.A. Vizantiyskiy Kherson VIXIII stoletiy v pamyatnikakh sfragistiki. 1. Chinovniki Khersona VIII-XI vv [Byzantine Cherson of the $6^{\text {th }}-$ $11^{\text {th }} \mathrm{cc}$. in the Monuments of Sphragistics. 1. Officials of Cherson of the $8^{\text {th }}-11^{\text {th }} \mathrm{cc}$.]. Sevastopol, OOO "Kolorit" Publ., 2017. 474 p. (Krym v istorii, kulture i ekonomike Rossii [Crimea in the History, Culture and Economy of Russia]).

12. Gertzen A.G., Alekseienko N.A. Vizantiyskie molivdovuly iz raskopok Mangup-Kale [Byzantinische Bleisiegel aus den Ausgrabungen von Mangup-Kale]. Antichnaya drevnost $i$ srednie veka [Antiquity and the Middle Ages], 2002, iss. 33, pp. 59-65.

13. Zubar V.M., Sorochan S.B. O polozhenii Khersona v kontse V-VI vv.: politicheskiy i ekonomicheskiy aspekty [On the Situation of Cherson at the End of the $5^{\text {th }}-6^{\text {th }}$ Centuries: Political and Economic Aspects]. Khersonesskiy sbornik, 1998, iss. IX, pp. 118-132.

14. Latyshev V.V. Sbornik grecheskikh nadpisey khristianskikh vremen iz Yuzhnoy Rossii [Collection of Greek Inscriptions of Christian Times from Southern Russia]. Saint Petersburg, Izd. Imperatorskogo 


\section{ВИЗАНТИЙСКАЯ СФРАГИСТИКА}

Russkogo arkheologicheskogo obshchesctva, 1896. $143 \mathrm{p}$.

15. Sokolova I.V. Vizantiyskie pechati VI - pervoy poloviny IX v. iz Khersonesa [Byzantine Lead Seals of the $6^{\text {th }}-$ First Half of the $9^{\text {th }}$ Century from Chersonesos]. Vizantiyskiy vremennik [Byzantina Xronika], 1991, vol. 52, pp. 201-213.

16. Sorochan S.B. Vizantiyskiy Kherson (vtoraya polovina $V I-$ pervaya polovina $X v v$.). Ocherki istorii i kultury. $V 2$ ch. Ch. 1 [Byzantine Cherson (Second Half of the $6^{\text {th }}-$ First Half of the $10^{\text {th }} \mathrm{cc}$.). Essays on History and Culture. In 2 Parts. Part 1]. Kharkiv, Maydan Publ., 2005. 1644 p.

17. Sorochan S.B. O dukakh vizantiyskoy Tavriki $\mathrm{i}$ ikh molivdovulakh [On the Doukai of the Byzantine Taurica and Their Molybdobullae]. Sugdeyskiy sbornik, 2008, iss. III, pp. 200-216.

18. Stepanova E.V. Pechati s latinskimi i grekolatinskimi nadpisyami VI-VIII vv. iz sobraniya Ermitazha [Seals with Latin and Greco-Latin Inscriptions of the $6^{\text {th }}-8^{\text {th }} \mathrm{cc}$. from the Hermitage Collection]. Saint Petersburg, Izd-vo Gosudarstvennyy Ermitazh, 2006. 170 p.

19. Khrapunov N.I. Administratsiya vizantiyskogo Khersona (kinets IV-XI st.): avtoref. dys. ... kand. ist. nauk [Administration of the Byzantine Cherson (Late $4^{\text {th }}-11^{\text {th }}$ cc.). Cand. hist. sc. abs. diss.]. Kiev, 2009. 20 p.

20. Khrapunov N.I. K diskussii o dolzhnosti duki Khersona [On the Discussion on the Position of the Doux of Cherson]. Vizantiyskiy vremennik [Byzantina Chronica], 2011, vol. 70 (95), pp. 37-50.

21. Tzuckerman C. Episkopy i garnizon Khersona v VI veke [Bishops and a Garrison in Cherson in the $4^{\text {th }}$ Century]. Materialy po arkheologii, istorii $i$ etnografii Tavrii [Materials in Archaeology, History and Ethnography of Tauria], 1995, iss. IV, pp. 545-651.

22. Brown T.S. Gentlemen and Officers. Imperial Administration and Aristocratic Power in Byzantine
Italy A.D. 554-800. London, British School at Rome, 1984. XIV, 288 p., 3 figs., 2 maps.

23. Bury J.B. The Imperial Administrative System in the Night Century. London, British Academy Publ., 1911. 179 p.

24. Fink W.O. Das byzantinische Monogramm. Diss. zur Erlangung des Doctorgrades. Wien, 1971. $473 \mathrm{~S}$.

25. Jones A.H.M. The Later Roman Empire, 284602. Vol. 1. Oxford, Blackwell Publ., 1992, XV, 766 p.

26. Laurent V. Documents de sigillographie byzantine: la collection C. Orghidan. Paris, Pr. univ. de France, 1952. 342 p., LXX pl.

27. Oikonomidus N. Les listes de préséance byzantines des IX et $X^{e}$ siècles. Paris, CNRS, 1972. $403 \mathrm{p}$.

28. Oikonomides N. A Collection of Dated Byzantine Lead Seals. Washington, Dumbarton Oaks Research Libr. a. Coll., 1986. 175 p.

29. Sode Cl. Byzantinische Bleisiegel in Berlin. Vol. II. Bonn, R. Habelt, 1997. 338 S., 25 Taf. (Poikila byzantina [Byzantine Miscellanea], vol. 14).

30. Speck P. Byzantinische Bleisiegel in Berlin (West). Bonn, R. Habelt, 1986. 261 S., 15 Taf. (Poikila byzantina [Byzantine Miscellanea], vol. 5).

31. Stein E. Histoire du Bas-Empire. Vol. 2. Paris, Desclée de Brouwer, 1949. 901 p.

32. Kazhdan A.P. et al., eds. The Oxford Dictionary of Byzantium. Vol. I. Oxford, Oxford Univ. Pr., 1991. LI, 728 p.

33. Zacos, G., Veglery, A. Byzantine Lead Seals. Vol. 1, Pt. I-III. Basel, J. J. Augustin Publ., 1972. 1965 p., $260 \mathrm{pl}$.

34. Koltsida-Makre I. Byzantina molybdoboulla sylloges Orphanide-Nikolande Numismatikou Mouseiou Athenon [Byzantine Lead Seals Collection of the Orphanides-Nikolaides Monetary Museum of Athens]. Athens, Ekd. Christianike Archaiologike Etaireia Publ., 1996.210p.

\section{Information about the Author}

Nikolay A. Alekseienko, Dr. Études médiévales (Paris IV-Sorbonne), Candidate of Sciences (History), Senior Researcher, Department of Medieval Archaeology, Institute of Archaeology of Crimea of the Russian Academy of Sciences, Prosp. Vernadskogo, 2, 295007 Simferopol, Russian Federation, alekseyenkonikolaj@gmail.com, https://orcid.org/0000-0003-1992-680X

\section{Информация об авторе}

Николай Александрович Алексеенко, Dr. Études médiévales (Paris IV-Sorbonne), кандидат исторических наук, старший научный сотрудник отдела средневековой археологии, Институт археологии Крыма РАН, просп. Академика В.И. Вернадского, 2, 295007 г. Симферополь, Российская Федерация, alekseyenkonikolaj@gmail.com, https:/orcid.org/0000-0003-1992-680X 